\title{
In vitro efficacy of Coriandrum sativum, Lippia sidoides and Copaifera reticulata against Leishmania chagasi
}

\author{
Eficácia in vitro de Coriandrum sativum, Lippia sidoides e Copaifera reticulata sobre Leishmania chagasi \\ Fernanda Cristina Macedo Rondon ${ }^{1}$; Claudia Maria Leal Bevilaqua ${ }^{1 *}$; Marina Parissi Accioly ${ }^{1}$; \\ Selene Maia de Morais $^{2}$; Heitor Franco de Andrade-Júnior ${ }^{3}$; Camila Aparecida de Carvalho ${ }^{3}$; \\ Josemar Coelho Lima ${ }^{4}$; Hilton César Rodrigues Magalhães ${ }^{4}$ \\ ${ }^{1}$ Laboratório de Doenças Parasitárias, Universidade Estadual do Ceará - UECE, Fortaleza, CE, Brasil \\ ${ }^{2}$ Laboratório de Química de Produtos Naturais, Universidade Estadual do Ceará - UECE, Fortaleza, CE, Brasil \\ ${ }^{3}$ Laboratório de Protozoologia, Universidade de São Paulo - USP, São Paulo, SP, Brasil \\ ${ }^{4}$ Laboratório de Análise de Alimentos, Embrapa Agroindústria Tropical, Fortaleza, CE, Brasil
}

Received April 12, 2011

Accepted May 16, 2012

\begin{abstract}
The increased incidence of visceral leishmaniasis $(\mathrm{VL})$ in Brazil is due to a lack of effective disease control measures. In addition to that, no effective treatment exists for canine VL in response to synthetic drugs. Thus, the objective of this study was to evaluate the effect of the essential oils of Coriandrum sativum and Lippia sidoides, and oleoresin from Copaifera reticulata, on Leishmania chagasi promastigotes and amastigotes. We also examined the toxicity of these treatments on the murine monocyte cell line RAW 264.7. To determine the IC50 a MTT test (3-(4,5-Dimethylthiazol2-yl)-2,5-diphenyltetrazolium bromide) was performed on promastigotes, and an in situ ELISA assay was conducted on amastigotes. Here, we demonstrate that oleoresin from C. reticulata was effective against both promastigotes (IC50 of $7.88 \mu \mathrm{g} \cdot \mathrm{mL}^{-1}$ ) and amastigotes (IC50 of $0.52 \mu \mathrm{g} \cdot \mathrm{mL}^{-1}$ ), and neither of the two treatments differed significantly ( $\mathrm{p}>0.05$ ) from pentamidine (IC50 of $2.149 \mu \mathrm{g} \cdot \mathrm{mL}^{-1}$ ) and amphotericin B (IC50 of $9.754 \mu \mathrm{g} \cdot \mathrm{mL}^{-1}$ ). Of the three plant oils tested, only oleoresin showed no toxicity toward monocyte, with $78.45 \%$ viability after treatment. Inhibition of promastigote and amastigote growth and the lack of cytotoxicity by $C$. reticulata demonstrate that oleoresin may be a viable option for analyzing the in vivo therapeutic effects of leishmanicidal plants
\end{abstract}

Keywords: Leishmanicidal plants, oils, cytotoxicity, amastigotes, promastigotes, Leishmania chagasi.

\section{Resumo}

O aumento na incidência da Leishmaníase Visceral (LV) no Brasil deve-se à ineficácia das medidas de controle da doença. Além disso, não há tratamento efetivo para LV canina com drogas sintéticas. Assim, o objetivo deste trabalho foi avaliar o efeito dos óleos essenciais de Coriandrum sativum e de Lippia sidoides e do óleo-resina de Copaifera reticulata sobre promastigotas e amastigotas de Leishmania chagasi e analisar o grau de toxicidade sobre células monocíticas murinas RAW 264.7. Para determinar a CI50 sobre promastigotas foi usado teste MTT (brometo de 3-[4,5-dimetiltiazol-2-il]-2,5-difeniltetrazólio) e sobre amastigotas foi realizado imunoensaio in situ pela técnica de ELISA. Os resultados obtidos comprovaram que o óleo-resina de C. reticulata foi o mais eficaz contra as formas promastigotas

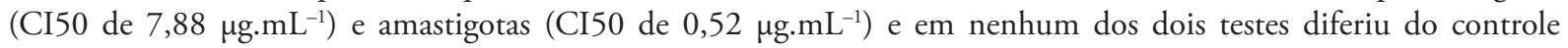

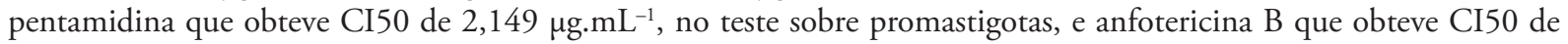
$9,754 \mu \mathrm{g} \cdot \mathrm{mL}^{-1}$, nos testes com amastigotas $(\mathrm{p}>0.05)$. Quanto à citotoxicidade apenas o óleo-resina não apresentou toxicidade com 78,45\% de monócitos viáveis. Os resultados obtidos sobre promastigotas e amastigotas e a ausência de citotoxicidade do óleo-resina de $C$. reticulata evidenciam que este óleo-resina pode ser viável para a análise de seus efeitos terapêuticos em testes in vivo.

Palavras-chave: Plantas leishmanicidas, óleos, citotoxicidade, amastigotas, promastigotas, Leishmania chagasi.

\footnotetext{
${ }^{*}$ Corresponding author: Claudia Maria Leal Bevilaqua

Laboratório de Doenças Parasitárias, Programa de Pós-graduaçáo em Ciências

Veterinárias, Faculdade de Veterinária, Universidade Estadual do Ceará - UECE,

Av. Dedé Brasil, 1700, CEP 60714-903, Fortaleza, CE, Brasil

e-mail: claudia.bevilaqua@pq.cnpq.br
} 


\section{Introduction}

The World Health Organization (WHO) considers visceral leishmaniasis (VL) to be a major tropical zoonotic disease (MISHRA et al., 2009). VL, which continues to resist modern control efforts, is most common in northeastern Asia, eastern Africa and northeastern Brazil, but cases also occur in southern Europe and elsewhere. Each year, there are approximately 500,000 new cases and more than 50,000 deaths worldwide; however, because leishmaniasis is not a commonly reported disease in many countries, these values are probably underestimated (WHO, 2010). In Brazil, this disease has expanded throughout the canine and human populations in various regions (RONDON et al., 2008; BRASIL, 2009). In addition, infected dogs have been associated with all human disease outbreaks, representing the main link in the chain of transmission, and, despite the existence of other Leishmania reservoirs, such as horses and cats, dogs are the only confirmed domestic reservoir (GRAMICCIA; GRADONI, 2005).

Until now, canine visceral leishmaniasis (CVL) has proven to be resistant to available synthetic antiparasitic drugs, thus reinforcing the need for alternatives in disease control. CVL therapies aim to reduce the parasite load, minimize organ damage by the parasites, and redirect the immune response to improve animal health and prevent relapse (OLIVA et al., 2010).

Alternative methods of parasite control, including deltamethrinimpregnated collars or spot-on permethrin-based topical insecticides, are being employed in an attempt to block transmission (MAROLI et al., 2010). Furthermore, the use of plants for new medicines has increased, both to combat multidrug-resistant parasites and to maximize disease control (CROFT; COOMBS, 2003; SHARIEF et al., 2006).

Essential oils are natural products of great medical importance because they already possess proven anti-fungi, antimicrobial, and antileishmanial activities (ANTHONY et al., 2005; OLIVEIRA et al., 2009).

The essential oil of $L$. sidoides, popularly called alecrim-pimenta, belongs to the family Verbenaceae. It has been previously tested against Aedes aegypti (CARVALHO et al., 2003; CAVALCANTI et al., 2004), Haemonchus contortus, Syphacia obvelata and Aspiculuris tetraptera (CAMURÇA-VASCONCELOS et al., 2007) and has proven anti-inflammatory, gastroprotective, antioxidant (MONTEIRO et al., 2007) and anti-fungi activities (FONTENELLE et al., 2007). C. reticulata oleoresin, commonly called, óleo de Copaíba in Portuguese, belongs to the family Fabaceae. It has been evaluated against Culex quinquefasciatus as well as $A$. aegypti (SILVA et al., 2003; GERIS et al., 2008) and has proven activity anti-Trypanosoma and anti-Leishmania (MACIEL et al., 2002; VEIGA JUNIOR; PINTO, 2002). C. sativum, called coentro in Portuguese, belongs to the family Umbelliferae and has antimutagenic (CORTÉS-ESLAVA et al., 2004), antidiabetic (GALLAGHER et al., 2003), diuretic (AISSAOUI et al., 2008), gastroprotective (AL-MOFLEH et al., 2006), anti-fungi (ATANDA et al., 2007), as well as anxiolytic effects (EMAMGHOREISHI et al., 2005). This herbal is also effective against $H$. contortus (EGUALE et al., 2007).

The objective of this study was to evaluate the effect of the essentials oils of Coriandrum sativum and Lippia sidoides and oleoresin from Copaifera reticulata on L. chagasi promastigotes and amastigotes, as well as their cytotoxicities in the murine monocyte cell line RAW 264.7.

\section{Materials and Methods}

\section{Extraction of essential oils and oleoresins}

The essential oil of $L$. sidoides was purchased from PRONAT (Produtos Naturais LTDA). C. reticulata oleoresin and C. sativum seeds were purchased at a street fair in the state of Pará and the state of Ceará, Brazil, respectively. C. sativum seeds were dried for one week, and the essential oil was extracted by steam distillation.

\section{Phytochemical tests}

Qualitative phytochemical tests of phenols, tannins, catechins, leucoanthocyanidins, flavonoids, steroids, terpenes, alkaloids, and saponins were performed according to Matos (2009) and Siddiqui et al. (2009). These tests are based on the visual observation of colorimetric changes or on the formation of a precipitate after the addition of specific reagents.

\section{Chemical analysis}

The oils were chemically analyzed at the Laboratório de Análise de Alimentos, EMBRAPA/Agroindústria using gas chromatography/mass spectrometry (GC/MS) on a 5971 GC/MS (Hewlett-Packard ${ }^{\circledR}$ ) at a temperature of $270{ }^{\circ} \mathrm{C}$. Constituent molecules were identified by their retention indices and mass spectra compared to a database of known chemical signatures (ALENCAR et al., 1984; ADAMS, 1989).

\section{Cultivation of Leishmania chagasi}

Promastigotes of $L$. chagasi strain MHOM46/LC/HZ1 (Laboratório de Protozoologia/USP) were grown in M199 $\left(\right.$ Cultilab $\left.^{\circledR}\right)$ supplemented with $10 \%$ fetal calf serum (FCS) $\left(\right.$ Cultilab $\left.^{\circledR}\right)$, HEPES (Sigma-Aldrich $\left.{ }^{\circledR}\right)$, bovine hemin $\left(\right.$ Inlab $\left.^{\circledR}\right)$, sodium bicarbonate (Sigma-Aldrich $\left.{ }^{\circledR}\right)$, gentamicin $\left(40 \mathrm{mg} \cdot \mathrm{mL}^{-1}\right)$ $\left(\right.$ Inlab $\left.^{\circledR}\right)$, and 5\% human male sterile urine. Cultures were maintained in a BOD incubator at $23.6{ }^{\circ} \mathrm{C}$, and were passaged every three to four days.

Amastigotes (Laboratório de Protozoologia/USP) were cultured with the murine monocyte cell line RAW 264.7 (Sigma-Aldrich ${ }^{\circledR}$ ) in 96 well microplates. Cells were counted in a Neubauer chamber and plated at a density of $1 \times 10^{4} \mathrm{cells} / \mathrm{well}$. Promastigotes were added at a ratio 10:1 parasites to cell. Cells were cultured in Dulbecco's medium $\left(\mathrm{Cultilab}^{\circledR}\right)$ with 5\% FCS, sodium bicarbonate, and $40 \mathrm{mg} \cdot \mathrm{mL}^{-1}$ gentamicin. Bottles were kept ajar and cultivated under glass with $5 \% \mathrm{CO}_{2}$ at $36.6^{\circ} \mathrm{C}$. After 24 hours, the amastigotes inside the monocyte cells were observed under inverted microscope. 


\section{Assays on L. chagasi promastigotes}

Promastigotes were counted in a Neubauer chamber and used at a concentration of $1 \times 10^{5}$ promastigotes/well. On the first step, the oils of each plant were dissolved in ethanol, this solution was called the stock solution. On the second step, $100 \mu \mathrm{L}$ of stock solution was diluted in milli-Q water add M199 medium for promastigotes or Dulbecco's medium for amastigotes. The oil solution was evaluated at $6.25,12.5,25,50$, and $100 \mu \mathrm{g} \cdot \mathrm{mL}^{-1}$, as previously described by Tempone et al. (2005). After a 24-h incubation with the relevant compound, a tetrazolium dye (MTT) colorimetric assay (bromide 3-4.5-dimethylthiazol-2-yl-2.5-dephenyltetrazolium) was performed on promastigotes to determine viability, and the IC50 of each treatment was calculated. The positive control for this assay was pentamidine, and the negative control was M199 medium. All oils were assayed in triplicate. The MTT assay was analyzed on a Multiskan MS (UNISCIENCE $^{\circledR}$ ) microplate reader at a wavelength of $570 \mathrm{~nm}$.

\section{Assays on L. chagasi amastigotes}

Plant oils were diluted in milli-Q water to $6.25,12.5,25$, 50 and $100 \mu \mathrm{g} \cdot \mathrm{mL}^{-1}$ and then added to microplates containing a confluent layer of cells and amastigotes. An in situ enzyme-linked immunosorbent assay (ELISA) to determine the IC50 was performed according to the method of Piazza et al. (1994). Prior to treatment, infected cells were stained, and parasites were observed by microscopy. Experiments were performed on cells exhibiting greater than $50 \%$ infection in a given microscope field. Briefly, after a 24 hours incubation with the indicated plant oil, a solution of $0.01 \%$ saponin (Sigma-Aldrich ${ }^{\circledR}$ ) and $1 \%$ bovine serum albumin (BSA; Sigma-Aldrich ${ }^{\circledR}$ ) in 1X phosphate-buffered saline (PBS) was added to each well, and plates were incubated for 30 minutes at $37^{\circ} \mathrm{C}$. Wells were subsequently blocked with $5 \%$ nonfat dry milk $\left(\right.$ Nestle $\left.^{\circledR}\right)$ in PBS for 30 minutes at $37^{\circ} \mathrm{C}$. Microplates were washed and dried three times and then anti-L. chagasi serum, diluted 1:500 in 1X PBS containing 3\% milk, 0.05\% Tween 20 (PBSLT) and 10\% FCS, was added, and plates were incubated at $37^{\circ} \mathrm{C}$ overnight. Horseradish peroxidase-conjugated anti-rabbit IgG $\left(\right.$ Sigma-Aldrich $\left.{ }^{\circledR}\right)$ was diluted 1:10,000 in PBSLT and, after further washing, ortho-phenylenediamine chromogen (OPD) (Sigma-Aldrich ${ }^{\circledR}$ ) was added. To stop the reaction, $4 \mathrm{~N}$ chloric acid (Novaquímica ${ }^{\circledR}$ ) was added, and plates were read on a microplate reader using a $492 \mathrm{~nm}$ filter. The positive control for this assay was
$40 \mu \mathrm{g} . \mathrm{mL}^{-1}$ amphotericin B (Sigma-Aldrich ${ }^{\circledR}$ ), and the negative control was Dulbecco medium alone. To generate anti-L. chagasi antibodies, rabbits were immunized with promastigotes, and serum was obtained 30 days after immunization.

\section{Cytotoxicity assay}

RAW 264.7 cells (Sigma-Aldrich ${ }^{\circledR}$ ) were grown in 96 well microplates and treated with $100 \mu \mathrm{g} \cdot \mathrm{mL}^{-1}$ of plant oils. Subsequent testing was performed in situ by ELISA, as described above. The positive control in this step was $40 \mu \mathrm{g} \cdot \mathrm{mL}^{-1}$ amphotericin B (Sigma-Aldrich ${ }^{\circledR}$ ), and the negative control was Dulbecco medium. Readings were performed using a $492 \mathrm{~nm}$ filter in a microplate reader.

\section{Statistical analysis}

The drug concentrations that achieved a 50\% inhibition in the growth of parasites (IC50) were calculated using a nonlinear regression curve, with a $95 \%$ confidence interval. A one-way analysis of variance was the statistical method used to evaluate the response. Pair wise comparisons of means were made using Tukeys procedure. A p-value $<0.05$ was considered significant. For normalization, $100 \%$ survival was computed as the OD of the control containing only promastigotes or amastigotes, and/or cells alone.

\section{Results}

The results of oil activity on promastigotes showed that $C$. reticulata oleoresin and $L$. sidoides essential oil were effective compared with positive control pentamidine ( $\mathrm{p}>0.05)$. C. sativum essential oil was not effective against promastigotes of $L$. chagasi and was different from positive control $(\mathrm{p}<0.05)$. The assay on amastigotes demonstrated that the three oils were effective, and they were not significantly different from amphotericin B $(\mathrm{p}>0.05)$ (Table 1$)$.

The oleoresin from C. reticulata was not toxic to RAW 264.7 cells; the cells displayed $78.45 \%$ cell viability, which did not differ significantly from positive and negative controls $(\mathrm{p}>0.05)$. In contrast, the other oils demonstrated some toxicity; $49.9 \%$ viability was observed in cells treated with $C$. sativum, and $57.8 \%$ viability was observed in cells treated with $L$. sidoides. These results were

Table 1. IC50 values of Coriandrum sativum and Lippia sidoides essential oils, and Copaifera reticulata oleoresin on promastigotes and amastigotes of Leishmania chagasi.

\begin{tabular}{lcccccc}
\hline \multicolumn{1}{c}{ Plants } & $\begin{array}{c}\text { Promastigotes } \\
\text { IC50 }\left(\boldsymbol{\mu g} \cdot \mathbf{m L}^{-1}\right)\end{array}$ & CI95\% & p values & $\begin{array}{c}\text { Amastigotes } \\
\text { IC50 }\left(\boldsymbol{\mu g} \cdot \mathbf{m L}^{-1}\right)\end{array}$ & CI95\% & p values \\
\hline Copaifera reticulata & $7.88^{\mathrm{a}}$ & $1.52-40.86$ & 0.1458 & $0.52^{\mathrm{a}}$ & $0.05-5.39$ & 0.0851 \\
Coriandrum sativum & $181.00^{\mathrm{b}}$ & $67.53-269.60$ & 0.0019 & $1.51^{\mathrm{a}}$ & $0.06-37.64$ & 0.0851 \\
Lippia sidoides & $19.76^{\mathrm{a}}$ & $11.00-38.98$ & 0.1458 & $5.07^{\mathrm{a}}$ & $0.47-54.33$ & - \\
Positive Control & & & & - & - & - \\
Pentamidine & $2.149^{\mathrm{a}}$ & $0.07-58.14$ & 0.1458 & $-0.754^{\mathrm{a}}$ & $0.01-263.40$ & 0.0851 \\
Amphotericin B & - & - & - & & & \\
\hline
\end{tabular}

Means with the same letter are not significantly different $(\mathrm{p}>0.05)$. 
significantly different from the positive and negative controls and to oleoresin C. reticulata $(\mathrm{p}<0.05)$ (Figure 1$)$.

Phytochemical analysis revealed the presence of terpenoids in the extracted oils. Further characterization determined that the principal constituents of $L$. sidoides essential oil, $C$. sativum essential oil and $C$. reticulata oleoresin were thymol (59.65\%), $\beta$-linalool (73.21\%) and $\beta$-caryophyllene (43.18\%), respectively (Table 2).

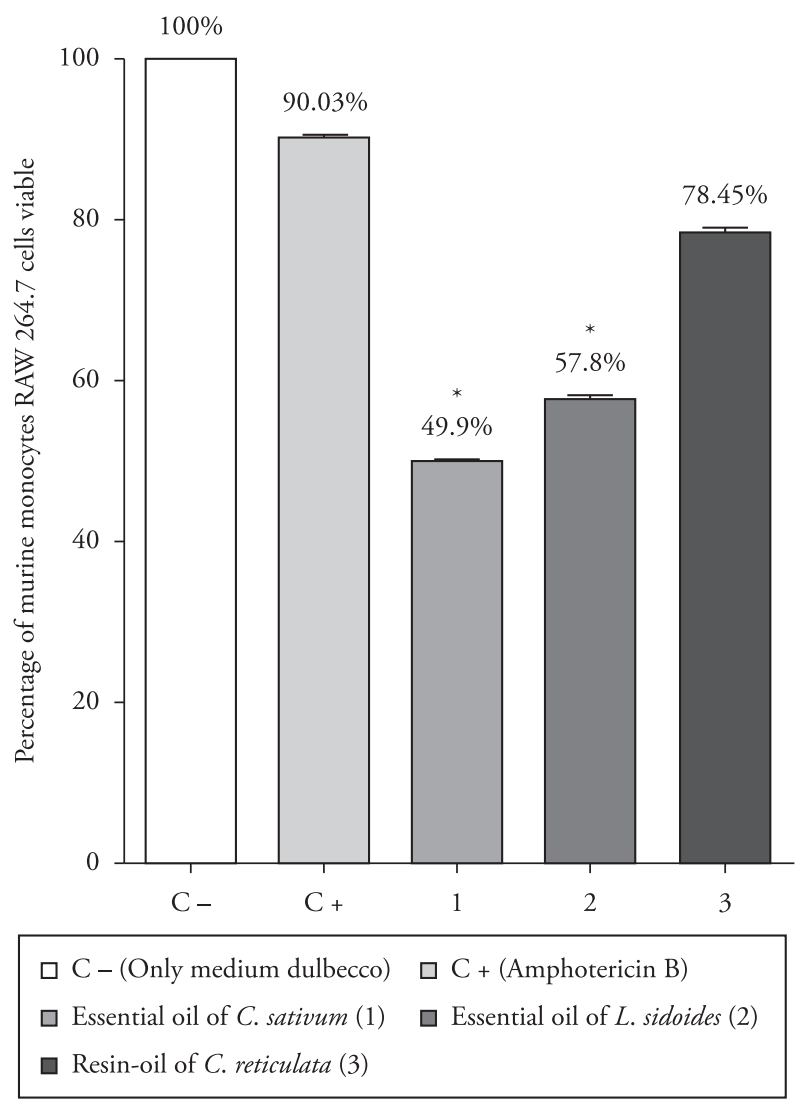

Figure 1. Effect of C. sativum and L. sidoides essentials oils, and C. reticulata oleoresin at a concentration of $100 \mu \mathrm{g} \cdot \mathrm{mL}^{-1}$, on the viability of the murine monocyte cell line, RAW 264.7. Amphotericin $\mathrm{B}\left(40 \mu \mathrm{g} \cdot \mathrm{mL}^{-1}\right)$ was used as a reference, and Dulbecco medium served as the negative control. ${ }^{*} \mathrm{p}<0.05^{1}$. ${ }^{1}$ The star symbol shows statistical difference between treatments 1 and 2 related to treatment 3 and the positive and negative controls $(\mathrm{p}<0.05)$. The treatment 1 is not statistically different from treatment 2 ( $\mathrm{p}>0.05)$.

Table 2. Relative composition (\%) of Coriandrum sativum and Lippia sidoides essential oils, and Copaifera reticulata oleoresin.

\begin{tabular}{clc}
\hline \multicolumn{1}{c}{ Plants } & Constituents & Percentage (\%) \\
\hline \multirow{3}{*}{ Copaifera reticulata } & $\beta$-Caryophyllene & 43.18 \\
& $\alpha$-Bergamotene & 8.76 \\
& Copaene & 8.69 \\
\hline \multirow{3}{*}{ Coriandrum sativum } & $\beta$-linalool & 73.21 \\
& Camphor & 4.25 \\
& $\alpha$-Pinene & 4.20 \\
\hline \multirow{2}{*}{ Lippia sidoides } & Thymol & 59.65 \\
& $\beta$-Caryophyllene & 10.60 \\
& Cymene & 9.08 \\
\hline
\end{tabular}

\section{Discussion}

A study among eight plant species of the genus Copaifera (C. multijuga, C. officinalis, C. reticulata, C. lucens, C. langsdorffii, C. paupera, C. martii, and C. cearensis), related that C. reticulata demonstrated the greatest efficacy against Leishmania amazonensis, with IC50 values of $5 \mu \mathrm{g} \cdot \mathrm{mL}^{-1}$ on promastigotes and $20 \mu \mathrm{g} \cdot \mathrm{mL}^{-1}$ on amastigotes. This oil also exhibited a low level of toxicity toward the murine macrophage cell line J774G8 (SANTOS et al., 2008). The results showed that $C$. reticulata had IC50 values against promastigotes of $L$. chagasi similar to IC50 values on promastigotes of $L$. amazonensis found by Santos et al. (2008). However the oleoresin had proven to be even more effective against $L$. chagasi amastigotes (IC50 $0.52 \mu \mathrm{g} \cdot \mathrm{mL}^{-1}$ ). The differing IC50 values obtained with $C$. reticulata oleoresin on amastigotes of $L$. amazonensis and $L$. chagasi can be explained by differences in target. The potential targets of leishmanicidal drugs are glucose transport system, purines and other essential biomolecules and several important and specific enzyme systems of Leishmania (BARRETT et al., 1999; DOERIG et al., 2002; PADMANABHAN et al., 2005).

Oliveira et al. (2009) had previously investigated the activity of essential oils from Cymbopogon citratus, L. sidoides and Ocimum gratissimum against promastigotes of $L$. chagasi. In this study, the most effective compound was $C$. citratus, with an IC50 of $45 \mu \mathrm{g} \cdot \mathrm{mL}^{-1}$, followed by the oil of $O$. gratissimum, with an IC50 of $75 \mu \mathrm{g} . \mathrm{mL}^{-1}$; the least effective essential oil was L. sidoides, with an IC50 of $89 \mu \mathrm{g} \cdot \mathrm{mL}^{-1}$. Another study performed on promastigotes and amastigotes of $L$. chagasi reported that essential oils from plants of the genus Lippia were effective in inhibiting promastigote infection, with IC50 values of $4.4 \mu \mathrm{g} \cdot \mathrm{mL}^{-1}$ for L. origanoides, $5.2 \mu \mathrm{g} . \mathrm{mL}^{-1}$ for L. citriodora, $18.9 \mu \mathrm{g} \cdot \mathrm{mL}^{-1}$ for L. alba, and $51.8 \mu \mathrm{g} \cdot \mathrm{mL}^{-1}$ for L. micromera. No oil had demonstrated inhibition of intracellular amastigotes in the human monocyte line THP-1 (ESCOBAR et al., 2010). In contrast, in the present work, $L$. sidoides oil exhibited the greatest activity against both promastigotes and amastigotes of $L$. chagasi. The difference between the IC50 values may be due to the composition of the oils, which is highly variable, depending on the soil where the plant was grown, the time of collection, environmental factors and other effects (MARTINS et al., 2006; NOGUEIRA et al., 2007).

The effect of $C$. sativum essential oil against Leishmania parasites had never been reported, actually only one study was published with three fractions of $C$. sativum against Leishmania infantum (RONDON et al., 2011). In this study, the results against promastigotes and amastigotes were contradictory because all fractions had effect on promastigotes but the ethyl acetate fraction did not act on amastigotes. Among the results on promastigotes, the chloroform fractions demonstrated the higher IC50 value and only this fraction showed terpenoids in qualitative chemical analysis. Other studies reported the effect of $C$. sativum essential oil against microorganisms like Candida spp. (SILVA et al., 2011a), Gram-positive and Gram-negative bacteria (SILVA et al., 2011b).

The main constituents of $C$. sativum, $L$. sidoides and $C$. reticulata oils were the monoterpenes $\beta$-linalool and thymol, and the sesquiterpene $\beta$-caryophyllene, respectively. Similar findings were obtained by Ghannadi and Sadeh (1999) for C. sativum, 
Camurça-Vasconcelos et al. (2007) for L. sidoides and Santos et al. (2008) for C. reticulata.

The mechanism of action of linalool found in the fruit of C. sativum is to stimulate the production of reactive oxygen species, such as nitric oxide (NO), to inhibit the activity of mitochondrial respiratory chain and to decrease levels of ATP and glutathione in the cells (USTA et al., 2009). Rosa et al. (2003) investigated the effects of linalool from essential oil of Croton cajucara against Leishmania amazonensis and on macrophage-parasite interactions. This compound had effect on both parasites forms and produced twice the amount of $\mathrm{NO}$ as the non treated macrophages. It reinforces the model that linalool acts indirectly to favor NO production by macrophages to eradicate the infection with Leishmania spp. C. sativum essential oil is rich in linalool. Such oil was more effective on amastigotes.

Thymol, a terpenoid, causes structural and functional damage to the cell membrane and acts directly on the synthesis and activity of ATPase and on the concentration of potassium and phosphate ions in the parasite. These activities have been characterized in bacteria, and this is the likely mechanism of action against Leishmania (LAMBERT et al., 2001; OSORIO et al., 2006). Synthetic thymol compounds exhibited an IC50 of $194.3 \mu \mathrm{g} \cdot \mathrm{mL}^{-1}$ against promastigotes of Leishmania panamensis (ROBLEDO et al., 2005). In another study, a thymol-rich $L$. sidoides essential oil showed an IC50 of $89 \mu \mathrm{g} \cdot \mathrm{mL}^{-1}$ against L. chagasi (OLIVEIRA et al., 2009). The essential oil of L. citriodora, which is also rich in thymol, demonstrated an IC50 of $4.4 \mu \mathrm{g} \cdot \mathrm{mL}^{-1}$ on L. chagasi promastigotes (ESCOBAR et al., 2010). In this report, the essential oil of L. sidoides proved to be rich in thymol and yielded an IC50 of $19.76 \mu \mathrm{g} \cdot \mathrm{mL}^{-1}$ on promastigotes of the same species. Synthetic thymol exhibited higher IC50 values than the essential oils, which are composed of natural thymol and other substances. Thus, the more effective action of the oils may be due to the synergistic effect of other compounds, such as caryophyllene and cymene, or perhaps thymol is not as potent against L. panamensis compared to L. chagasi.

While the mechanism of action of $\beta$-caryophyllene is not well understood, it is effective against $L$. amazonensis (SANTOS et al., 2008) and exhibits anti-inflammatory (SHIMIZU et al., 1990), antimicrobial and antioxidant properties (SAHIN et al., 2004).

Investigations using natural products have shown great potential in finding new agents to fight tropical diseases, and the results here demonstrate that $C$. reticulata oleoresin is highly effective against promastigotes and amastigotes of $L$. chagasi, while exhibiting no toxicity toward the RAW 264.7 cell line. While further research is needed to prove its efficacy in vivo, C. reticulata oleoresin may be a promising new treatment for canine and human visceral leishmaniasis.

\section{Acknowledgements}

We would like to thank FUNCAP for financial support. Dr. Bevilaqua, Dr. Morais and Dr. Andrade-Junior have a grant from CNPq.

\section{References}

Adams RP. Identification of essential oils by ion trap mass spectroscopy. London: Academic Press; 1989. 456 p.

Aissaoui A, El-Hilaly J, Israili ZH, Lyoussi B. Acute diuretic effect of continuous intravenous infusion of an aqueous extract of Coriandrum sativum L. in anesthetized rats. J Ethnopharmacol 2008; 115(1): 89-95. PMid:17961943. http://dx.doi.org/10.1016/j.jep.2007.09.007

Alencar JW, Craveirto AA, Matos FJA. Kovats' indices as a preselection routine in mass spectra library searches of volatiles. $J$ Nat Prod 1984; 47(5): 890-892. http://dx.doi.org/10.1021/np50035a028

Al-Mofleh IA, Alhaide AA, Mossa JS, AL-Sohaibani MO, Rafatullah S, Qureshi S. Protection of gastric mucosal damage by Coriandrum sativum L. pretreatment in Wistar albino rats. Environ Toxicol Pharmacol 2006; 22(1): 64-69. http://dx.doi.org/10.1016/j. etap.2005.12.002

Anthony JP, Fyfe L, Smith H. Plant active components - a resource for antiparasitic agents? Trends Parasitol 2005; 21(10): 462-468. http:// dx.doi.org/10.1016/j.pt.2005.08.004

Atanda OO, Akpan I, Oluwafemi F. The potential of some spice essential oils in the control of $A$. parasiticus CFR 223 and aflatoxin production. Food Control 2007; 18(5): 601-607. http://dx.doi.org/10.1016/j. foodcont.2006.02.007

Barrett MP, Mottram JC, Coombs GH. Recent advances in identifying and validating drug targets in trypanosomes and leishmanias. Trends Microbiol 1999; 7(2): 82-88. http://dx.doi.org/10.1016/S0966842X(98)01433-4

Brasil. Ministério da Saúde. Secretaria de Vigilância em Saúde. Departamento de Vigilância Epidemiológica. Guia de vigilância epidemiológica: normas e manuais técnicos. 7. ed. Brasília:Ministério da Saúde; 2009. 816 p.

Camurça-Vasconcelos ALF, Bevilaqua CML, Morais SM, Maciel MV, Costa CTC, Macedo ITF, et al. Anthelmintic activity of Croton zehntneri and Lippia sidoides essential oils. Vet Parasitol 2007; 148(3-4): 288-294. http://dx.doi.org/10.1016/j.vetpar.2007.06.012

Carvalho AFU, Melo VM, Craveiro AA, Machado MI, Bantim MB, Rabelo EF. Larvicidal activity of the essential oil from Lippia sidoides Cham. against Aedes aegypti Linn. Mem Inst Oswaldo Cruz 2003; 98(4): 569-571. http://dx.doi.org/10.1590/S0074-02762003000400027

Cavalcanti ESB, Morais SM, Lima MAA, Santana EWP. Larvicidal activity of essential oils from brazilian plants against Aedes aegypti L. Mem Inst Oswaldo Cruz 2004; 99(5): 541-544. http://dx.doi.org/10.1590/ S0074-02762004000500015

Cortés-Eslava J, Goméz-Arroyo, Villalobos-Pietrini R, EspinosaAguirre JJ. Antimutagenicity of coriander (Coriandrum sativum) juice on the mutagenesis produced by plant metabolites of aromatic amines. Toxicol Lett 2004; 153(2): 283-292. http://dx.doi.org/10.1016/j. toxlet.2004.05.011

Croft SL, Coombs GH. Leishmaniasis - current chemotherapy and recent advances in the search for novel drugs. Trends Parasitol 2003; 19(11): 502-508. http://dx.doi.org/10.1016/j.pt.2003.09.008

Doerig C, Meijer L, Mottram JC. Protein kinases as drug targets in parasitic protozoa. Trends Parasitol 2002; 18(8): 366-371. http://dx.doi. org/10.1016/S1471-4922(02)02321-8 
Eguale E, Tilahun G, Debella A, Feleke A, Makonnen E. In vitro and in vivo anthelmintic activity of crude extracts of Coriandrum sativum against Haemonchus contortus. J Ethnopharmacol 2007; 110(3): 428-433. http://dx.doi.org/10.1016/j.jep.2006.10.003

Emamghoreishi M, Khasaki M, Aazam MF. Coriandrum sativum: evaluation of its anxiolytic effect in elevated plus-maze. J Ethnopharmacol 2005; 96(3): 365-370. http://dx.doi.org/10.1016/j. jep.2004.06.022

Escobar P, Leal SM, Herrera LV, Marinez JR, Stashenko E. Chemical composition and antiprotozoal activities of Colombian Lippia spp essential oils and their major components. Mem Inst Oswaldo Cruz 2010; 105(2): 184-190. http://dx.doi.org/10.1590/S007402762010000200013

Fontenelle ROS, Morais SM, Brito EH, Kerntopf MR, Brilhante RS, Cordeiro RA, et al. Chemical composition, toxicological aspects and antifungal activity of essential oil from Lippia sidoides Cham. J Antimicrob Chemother 2007; 59(5): 934-940. http://dx.doi.org/10.1093/jac/dkm066

Gallagher AM, Flatt PR, Duffy G, Abdel-Wahab YHA. The effects of traditional antidiabetic plants on in vitro glucose diffusion. Nutrit Res 2003; 23(3): 413-424. http://dx.doi.org/10.1016/S02715317(02)00533-X

Geris R, Silva IG, Silva HHG, Barison A, Rodrigues-Filho E, Ferreira AG. Diterpenoids from Copaifera reticulata Ducke with larvicidal activity against Aedes aegypti (L.) (Diptera: Culicidae). Rev Inst Med Trop São Paulo 2008; 50(1): 25-28.

Ghannadi A, Sadeh D. Volatile constituents of the fruit of Coriandrum sativum L. from Isfahan. DARU 1999; 7(4): 12-14.

Gramiccia M, Gradoni L. The current status of zoonotic leishmaniases and approaches to disease control. Int J Parasitol 2005; 35(11-12): 1169-1180. http://dx.doi.org/10.1016/j.ijpara.2005.07.001

Lambert RJW, Skandamis PN, Coote PJ, Nychas GJ. A study of the minimum inhibitory concentration and mode of action of oregano essential oil, thymol and carvacrol. J Appl Microbiol 2001; 91(3): 453-462. http://dx.doi.org/10.1046/j.1365-2672.2001.01428.x

Maciel MAM, Pinto AC, Veiga Junior VF. Plantas medicinais: a necessidade de estudos multidisciplinares. Quim Nova 2002; 25(3): 429-438. http:// dx.doi.org/10.1590/S0100-40422002000300016

Maroli M, Gradoni L, Oliva G, Castagnaro M, Crotti A, Lubas G. Guidelines for prevention of leishmaniasis in dogs. J Am Vet Med Assoc 2010; 236(11): 1200-1206. http://dx.doi.org/10.2460/ javma.236.11.1200

Martins FT, Santos MH, Polo M, Barbosa LCA. Variação química do óleo essencial de Hyptis suaveolens (L.) Poit., sob condições de cultivo. Quim Nova 2006; 29(6): 1203-1209. http://dx.doi.org/10.1590/S010040422006000600011

Matos FJA. Introdução à Fitoquímica Experimental. 3. ed. Fortaleza: UFC; 2009.45 p.

Mishra BB, Kale RR, Singh RK, Tiwari VK. Alkaloids: Future prospective to combat leishmaniasis. Fitoterapia 2009; 80(2): 81-90. http://dx.doi. org/10.1016/j.fitote.2008.10.009

Monteiro MVB, Melo Leite AK, Bertini LM, Morais SM, NunesPinheiro DC. Topical anti-inflammatory, gastroprotective and antioxidant effects os the essential oil of Lippia sidoides Cham. leaves. J Ethnopharmacol 2007; 111(2): 378-382. http://dx.doi.org/10.1016/j. jep.2006.11.036
Nogueira MA, Diaz G, Sakumo L. Caracterização química e atividade biológica do óleo essencial de Lippia Alba cultivada no Paraná. Rev Ciênc Farm Básica Apl 2007; 28(3): 273-278.

Oliva G, Roura X, Crotti A, Maroli M, Castagnaro M, Gradoni $\mathrm{L}$, et al. Guidelines for treatment of leishmaniasis in dogs. J Am Vet Med Assoc 2010; 236(11): 1192-1198. http://dx.doi.org/10.2460/ javma.236.11.1192

Oliveira VCS, Moura DM, Lopes JA, Andrade PP, Silva NH, Figueiredo RC. Effects of essential oils from Cymbopogon citratus (DC) Stapf., Lippia sidoides Cham., and Ocimun gratissimum L. on growth and ultrastructure of Leishmania chagasi promastigotes. Parasitol Res 2009; 104(5): 1053-1059. http://dx.doi.org/10.1007/s00436-008-1288-6

Osorio E, Arango G, Robledo S, Muñoz D, Jaramillo L, Vélez I. Antileishmanial and cytotoxic activity of synthetic aromatic monoterpens. Acta Farm Bonaerense 2006; 25(3): 405-413.

Padmanabhan PK, Mukherjee A, Singh S, Chattopadhyaya S, Gowri VS, Myler PJ, et al. Glyoxalase I from Leishmania donovani: A potential target for anti-parasite drug. Biochem Biophys Res Commun 2005; 337(4): 1237-1248. http://dx.doi.org/10.1016/j.bbrc.2005.09.179

Piazza RMF, Andrade Junior HJ, Umezawa ES, Katzin AM, Stolf AM. In situ immunoassay for the assessment of Trypanosoma cruzi interiorization and growth in cultured cells. Acta Trop 1994; 57(4): 301 306. http://dx.doi.org/10.1016/0001-706X(94)90075-2

Robledo S, Osorio E, Muñoz D, Jaramillo L, Restrepo A, Arango $\mathrm{G}$, et al. In vitro and in vivo cytotoxicities and antileishmanial activities of thymol and hemisynthetic derivates. Antimicrob Agents Chemother 2005; 49(4): 1652-1655. http://dx.doi.org/10.1128/ AAC.49.4.1652-1655.2005

Rondon FCM, Bevilaqua CML, Franke CR, Barros RS, Oliveira FR, Alcântara AC, et al. Cross-sectional serological study of Canine Leishmania infection in Fortaleza, Ceará, Brazil. Vet Parasitol 2008; 155(1-2): 24-31. http://dx.doi.org/10.1016/j.vetpar.2008.04.014

Rondon FCM, Bevilaqua CML, Accioly MO, Morais SM, Andrade Junior HF, Machado LK, et al. In vitro effect of Aloe vera, Coriandrum sativum and Ricinus communis fractions on Leishmania infantum and on murine monocytic cells. Vet Parasitol 2011; 178(3-4): 235-240. http:// dx.doi.org/10.1016/j.vetpar.2011.01.007

Rosa MSS, Mendonça-Filho RR, Bizzo HR, Rodrigues IA, Soares RMA, Souto-Padrón T, et al. Antileishmanial activity of a Linalool-rich essential oil from Croton cajucara. Antimicrob Agents Chemother 2003; 47(6): 1895-1901. http://dx.doi.org/10.1128/AAC.47.6.1895-1901.2003

Sahin F, Güllüce M, Daferera D, Sökmen A, Sökmen M, Polissiou $\mathrm{M}$, et al. Biological activities of the essential oils and methanol extract of Origanum vulgare spp. vulgare in the Eastern Anatolia region of Turkey. Food Control 2004; 15(7): 549-557. http://dx.doi.org/10.1016/j. foodcont.2003.08.009

Santos AO, Ueda-Nakamura T, Dias Filho BP, Veiga Junior VF, Pinto AC, Nakamura CV. Effect of brazilian copaiba oils on Leishmania amazonensis. J Ethnopharmacol 2008; 120(2): 204-208. http://dx.doi. org/10.1016/j.jep.2008.08.007

Sharief AH, Gasim Khalil EA, Theander TG, Kharazmi A, Omer SA, Ibrahim ME. Leishmania donovani: an in vitro study of antimony-resistant amphotericin B-sensitive isolates. Exp Parasitol 2006; 114(4): 247-252. http://dx.doi.org/10.1016/j.exppara.2006.03.016

Shimizu M, Shogawa H, Matsuzawa T, Yonezawa S, Hayashi T, Arisawa $\mathrm{M}$, et al. Anti-inflammatory constituents of topically applied crude 
drugs. IV. Constituents and anti-inflammatory effect of Paraguayan crude drug "Alhucema" (Lavandula latifolia Vill.). Chem Pharm Bull (Tokyo) 1990; 38(8): 2283-2284. http://dx.doi.org/10.1248/cpb.38.2283

Siddiqui S, Verma A, Rather AA, Jabeen F, Meghvansi MK. Preliminary phytochemicals analysis of some important medicinal and aromatic plants. Adv Biol Res 2009; 3(5-6): 188-195.

Silva F, Ferreira S, Duarte A, Mendonça DI, Domingues FC. Antifungal activity of Coriandrum sativum essential oil, its mode of action against Candida species and potential synergism with amphotericin B. Phytomedicine 2011a; 19(1): 42-47. http://dx.doi.org/10.1016/j. phymed.2011.06.033

Silva F, Ferreira S, Queiroz JA, Domingues FC. Coriander (Coriandrum sativum L.) essential oil: its antibacterial activity and mode of action evaluated by flow cytometry. J Med Microbiol 2011b; 60(10): 1479-1486. http://dx.doi.org/10.1099/jmm.0.034157-0

Silva IG, Zanon VOM, Silva HHG. Larvicidal activity of Copaifera reticulata Ducke oil-resin against Culex quinquefasciatus Say (Diptera: Culicidae). Neotrop Entomol 2003; 32(4): 729-732. http://dx.doi. org/10.1590/S1519-566X2003000400029
Tempone AG, Borborema SE, Andrade Junior HF, Amorin Gualda NC, Yogi A, Carvalho CS, et al. Antiprotozoal activity of Brazilian plant extracts from isoquinoline alkaloid-producing families. Phytomedicine 2005; 12(5): 382-390. http://dx.doi.org/10.1016/j. phymed.2003.10.007

Usta J, Kreydiyyeh S, Knio K, Barnabe P, Bou-Moughlabay Y, Dagher S. Linalool decreases HepG2 viability by inhibiting mitochondrial complexes I and II, increasing reactive oxygen species and decreasing ATP and GSH levels. Chem Biol Interact 2009; 180(1): 39-46. http:// dx.doi.org/10.1016/j.cbi.2009.02.012

Veiga Junior VF, Pinto AC. O gênero Copaifera L. Quim Nova 2002; 25(2): 273-286. http://dx.doi.org/10.1590/S010040422002000200016

World Health Organization - WHO. Bulletin of the World Health Organization - Education is key to controlling visceral leishmaniasis. 2010. [cited 2011 Feb 22]. Available from: http://www.who.int/bulletin/ volumes/88/1/10-040110/en/index.html. 